\title{
Size variations in the genus Gephyrocapsa during the Early Pleistocene in the eastern Mediterranean
}

\author{
Enrico Di Stefano (*), Sandro Caracausi $(*)$, Alessandro Incarbona (**), \\ SERENA FERRARo (*) \& SimONa Velardi $(*)$
}

\section{ABSTRACT}

The genus Gephyrocapsa, belonging to coccolithophores, has often been used in biostratigraphic and paleoceanographic studies of the late Cenozoic. This taxon exhibits a gradual increase in size during the Early Pleistocene which has been ascribed to evolutive and/or environmental processes and has been used for biostratigraphic purposes.

Here we show both biometric and relative abundance data of specimens of this genus between about 2.0 and $0.9 \mathrm{Ma}$, from sediments of the Ionian Sea (eastern Mediterranean). Measurements on the long axis of placoliths highlight a gradual size increase between the upper part of MNN 19a and the top of MNN 19d biozones. On the basis of the comparison with paleoenvironmental proxy data acquired on the same site, we rule out the influence of climate and oceanographic phenomena due to glacial/interglacial oscillations, on Gephyrocapsa spp. size variations. However, we argue that the climate/environmental forcing may have acted by longer-scale phenomena, for instance the growth of ice sheets and the subsequent sea surface cooling in the oceans. Finally, we suggest that the First Common Occurrence of Gephyrocapsa $>4.5 \mu \mathrm{m}$ and the First Occurrence of Gephyrocapsa $>5.0 \mu \mathrm{m}$ may approximate the Last Occurrence of Calcidiscus macintyrei in studies dealing with terrigenous sediments affected by severe reworking.

KEY WORDS: Gephyrocapsa spp., Biometry, Early Pleistocene, Ionian Sea.

\section{INTRODUCTION}

Following the original definition of KAMPTNER (1943), all placoliths with a bridge across the central area can be referred to the genus Gephyrocapsa. The first appearance of this genus occurred about $3.5 \mathrm{Ma}$ and can be ascribed to the NN15 Zone (MARTINI, 1971) in the lower Pliocene (Pirini-RaddrizZani \& VAlleri, 1977; SAMTLEBEN, 1980; RIO, 1982).

Living and fossil specimens have been grouped in different morphotypes and species on the basis of variations in placolith size, placolith bridge angle and shape, the central collar, roundness and the central area width (fig. 1) (Pujos-Lamy, 1976; BréHéret, 1978; SAmTleBen, 1980; BOLLMANN, 1997). Especially important for biostratigraphic purposes is the coccolith size (e.g. GARTNER, 1977; RAFFI \& RIO, 1979; MATSUOKA \& OKADA, 1990; RAFFI et alii, 1993) that in the Mediterranean bioprovince allowed the detailed subdivision of the Early Pleistocene,

(*) Università degli Studi di Palermo, Dipartimento delle Scienze della Terra e del Mare, Via Archirafi, 22 - 90123 Palermo, Italy.

$(* *)$ Università degli Studi di Palermo, Dipartimento delle Scienze della Terra e del Mare, Via Archirafi, 22 - 90123 Palermo, Italy. Corresponding author: e-mail: alessandro.incarbona@unipa.it; phone: +3909123864648. from about 1.6 Ma to about 0.9 Ma by three biohorizons (Rio et alii, 1990). After the first occurrence of specimens of Gephyrocapsa oceanica s.l. $\geq 4 \mu \mathrm{m}$ at about $1.6 \mathrm{Ma}$, there is a general increase in size of the coccoliths which culminates with the first occurrence of large Gephyrocapsa $>5.5 \mu \mathrm{m}$ at about $1.3 \mathrm{Ma}$. The Gephyrocapsa spp. population is radically modified at about $1.1 \mathrm{Ma}$, with the disappearance of all the specimens $\geq 4 \mu \mathrm{m}$ and is again diversified after about 0.9 Ma with a new radiation of Gephyrocapsa spp. $\geq 4 \mu \mathrm{m}$, including specimens with a bridge parallel to the short axis (BUKRY, 1973; RIO, 1982; RIO et alii, 1990). The origin of Pleistocene variations in the Gephyrocapsa size variations remains poorly known, although these variations have been interpreted as the result of evolutionary and/or environmental process by different authors (PUJOS-LAMY, 1976; BRÉHÉRET, 1978; SAMTLEBEN, 1980; RiO, 1982; GARD, 1988; MATSUOKA \& OKADA, 1990; RAFFI et alii, 1993).

We have measured biometric relationships of gephyrocapsid specimens and determined the relative abundance of different species in sediments retrieved from Ocean Drilling Program (ODP) Site 964 (Ionian Sea, eastern Mediterranean Sea) during the Early Pleistocene (between about 2.0-0.9 Ma), at a sample resolution of about $20 \mathrm{kyr}$. Results are compared to paleoenvironmental/paleoceanographic proxy data in order to test how Gephyrocapsa spp. modifications were affected by changes in the marine environment.

\section{MATERIAL AND METHODS}

ODP Site $964\left(36^{\circ} 15.62^{\prime} \mathrm{N}, 17^{\circ} 45.025^{\prime}, 3650 \mathrm{~m}\right.$ water depth) is located at the foot of the Calabrian Ridge near the Ionian Abyssal Plain (fig. 2). All holes of Site 964 are characterized by locally discontinuous and tectonically attenuated sedimentary sequences (EMEIs et alii, 1996). The sediment consists of brownish to greenish clayey nannofossil ooze and nannofossil clay. Numerous ash layers, ashy turbidites, discrete beds of tuffs and normally graded turbidites have been recognized. Volcanic glass fragments are intercalated throughout (EMEIS et alii, 1996; LouRENS, 2004). Erosional gaps at the base of turbidites and high-angle extensional faults have been observed and the construction of the magnetostratigraphic record was hindered by overprints that could not be removed (EMEIs et alii, 1996). A total of 59 sapropel layers are present in the composite section of Site 964 (SAKAмото et alii, 1998) and they were compared with the Plio-Pleistocene sections outcropping in south- 
ern Italy (SPROVIERI et alii, 1998; Di STEFANO \& INCARBONA, 2008).

In the present study, the portion between 63.14 and 32.94 revised meter composite depth (rmcd) has been selected and it represents the interval between the Gelasian Stage (MNN 18 Zone) and the Calabrian Stage (MNN 19f Zone) (SPROVIERI et alii, 1998). The lithology consists of brownish to greenish clayey nannofossil ooze and nannofossil clay and includes a thick turbidite layer between 52.98 and $49.46 \mathrm{rmcd}$.

Three different analyses were carried out by observation with a polarized microscope at about $1000 \times$ magnification, in rippled smear slides prepared following standard procedures (Bown \& Young, 1998). Axiocam Cci camera and software Axiovision 4.7 were used for length measurements of the long axis of 50 specimens of Gephyrocapsa spp. $>3 \mu \mathrm{m}$ in 45 samples. Following the biometric subdivision of Rio (1982) and Rio et alii (1990), small Gephyrocapsa includes specimens $<4 \mu \mathrm{m}$, medium Gephyrocapsa includes specimens between 4 and $5.5 \mu \mathrm{m}$, large Gephyrocapsa includes specimens $>5.5 \mu \mathrm{m}$. A different criterion was applied to describe the genus Gephyrocapsa in terms of species, evaluated versus 300 specimens of this taxon in 42 samples. Following INCARBONA et alii (2009) the species concept used are: very small Gephyrocapsa for specimens $<3 \mu \mathrm{m}$; Gephyrocapsa muellerae for specimens $>3 \mu \mathrm{m}$ with a low bridge angle; Gephyrocapsa caribbeanica for specimens $>3 \mu \mathrm{m}$ with an almost closed central area; Gephyrocapsa oceanica and Gephyrocapsa omega (or Gephyrocapsa sp. 3 sensu Rio, 1982) specimens were not distinguished one each other. They include specimens $>3 \mu \mathrm{m}$ with a high bridge angle. A total of 83 samples were analysed to determine the relative abundance of Florisphaera profunda versus 100 coccolithophore specimens (CASTRADORI, 1993; SPROVIERI et alii, 2003).

The instrumental uncertainty due to the Axiovision 4.7 software is of $0.005 \mu \mathrm{m}$ (1 pixel) and is therefore negligible. A further error in measurements may be given by the tilt of placoliths. However, the error would become significant $(>5 \%)$ if the tilt of placolith is $\geq 20^{\circ}$, which is rather unlikely and would prevent the correct identification at the species level.

\section{STUDY AREA}

Three water masses exist in the Ionian Sea. Modified Atlantic Waters occupy the upper 100-200 m of the water column. They enter from the northern part of the Sicily Strait, trasported by the Atlantic Ionian Stream that meanders into the Ionian Sea and feeds the Mid-Mediterranean Jet (Poem Group, 1992; Pinardi \& MasetTi, 2000). Levantine Intermediate Waters (LIW), located between 150-200 and $600 \mathrm{~m}$, formed in February-March as a process of surface cooling on water masses that underwent a severe salt enrichment in the area between Rhodes and Cyprus (OvCHINNIKOv, 1984; PoEM GrouP, 1992). Bottom waters, whose origin is due to the sinking of surface cooling and the mixing with LIW, form in the northern part of the basin, in the Adriatic and Aegean Sea (Poem Group, 1992).

The trophic resources of the eastern Mediterranean Sea are among the poorest in the world's oceans, and this deficit is especially pronounced with respect to phosphorous (KROM et alii, 2010). Productivity estimates in the

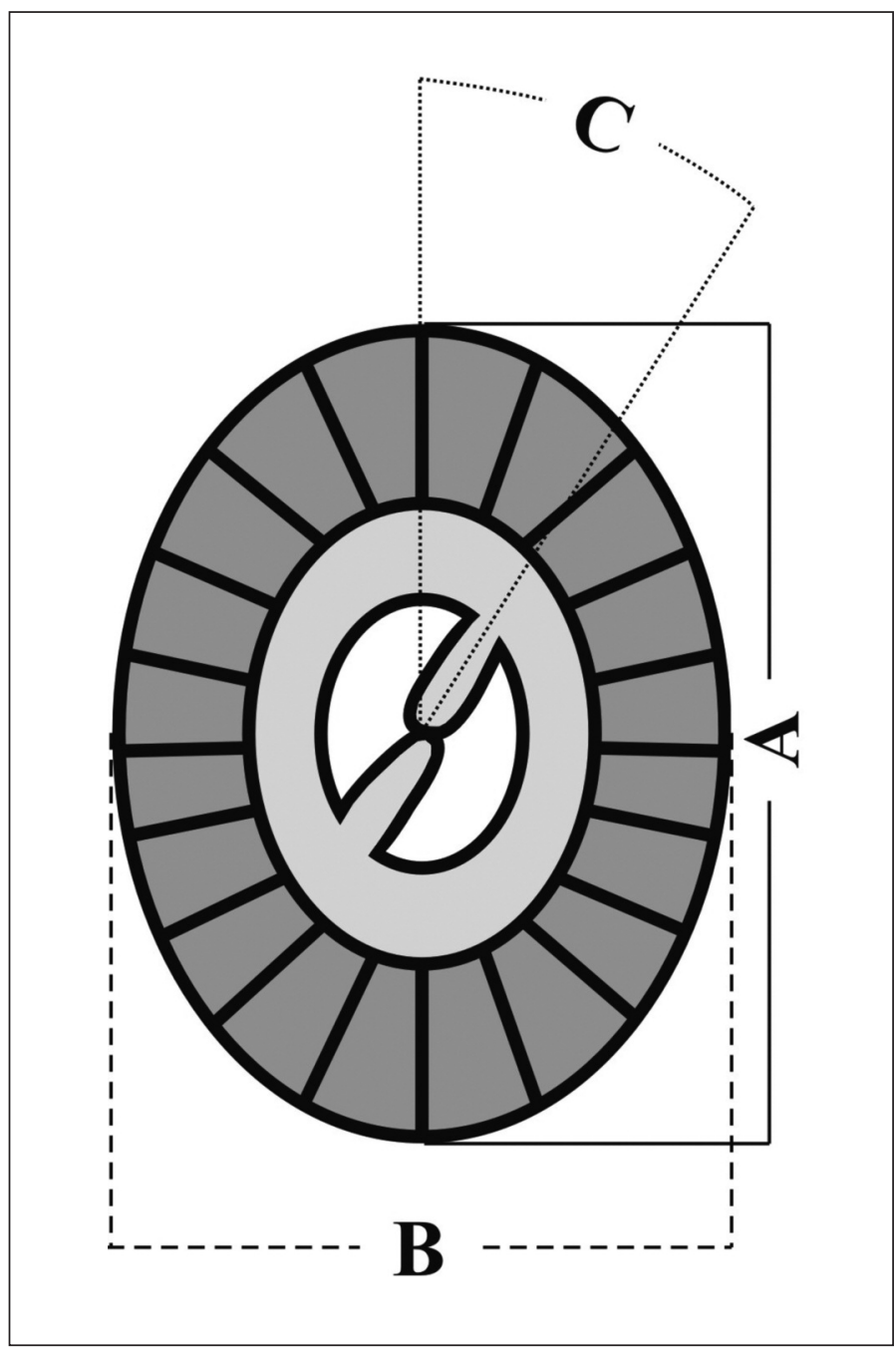

Fig. 1 - Cartoon showing some of the measurements that can be carried out on placoliths of the genus Gephyrocapsa: A) Long axis length; $B$ ) Short axis length; $C$ ) Bridge angle.

Ionian Sea range between about 105 and $130 \mathrm{gC} \times \mathrm{m}^{-2} \times \mathrm{yr}^{-1}$ and demonstrate that it is one of the most oligotrophic subbasins in the Mediterranean Sea (ANTOINE et alii, 1995; D'ORTENZIO et alii, 2003; Bosc et alii, 2004). In particular, Site 964 is located in an area characterized by low biomass during late spring-summer and higher biomass up to the maxima in late fall-winter (D'ORTENZIO \& RIBERA D’AlCALÀ, 2009).

\section{RESULTS}

Calcareous nannofossil assemblages are well diversified and preserved. However, in four samples, at 56.48, $41.77,40.36$ and $37.84 \mathrm{rmcd}$, severe dissolution processes led to the complete disappearance of Gephyrocapsa spp. specimens (fig. 3).

Gephyrocapsa spp. assemblages are dominated by very small specimens $(<3 \mu \mathrm{m})$, with relative abundance values between $70 \%$ and $100 \%$, apart from values of $40 \%$ in the uppermost sample (fig. 3). At distinct intervals, there is a significant contribution of $G$. muellerae, $G$. caribbeanica, 


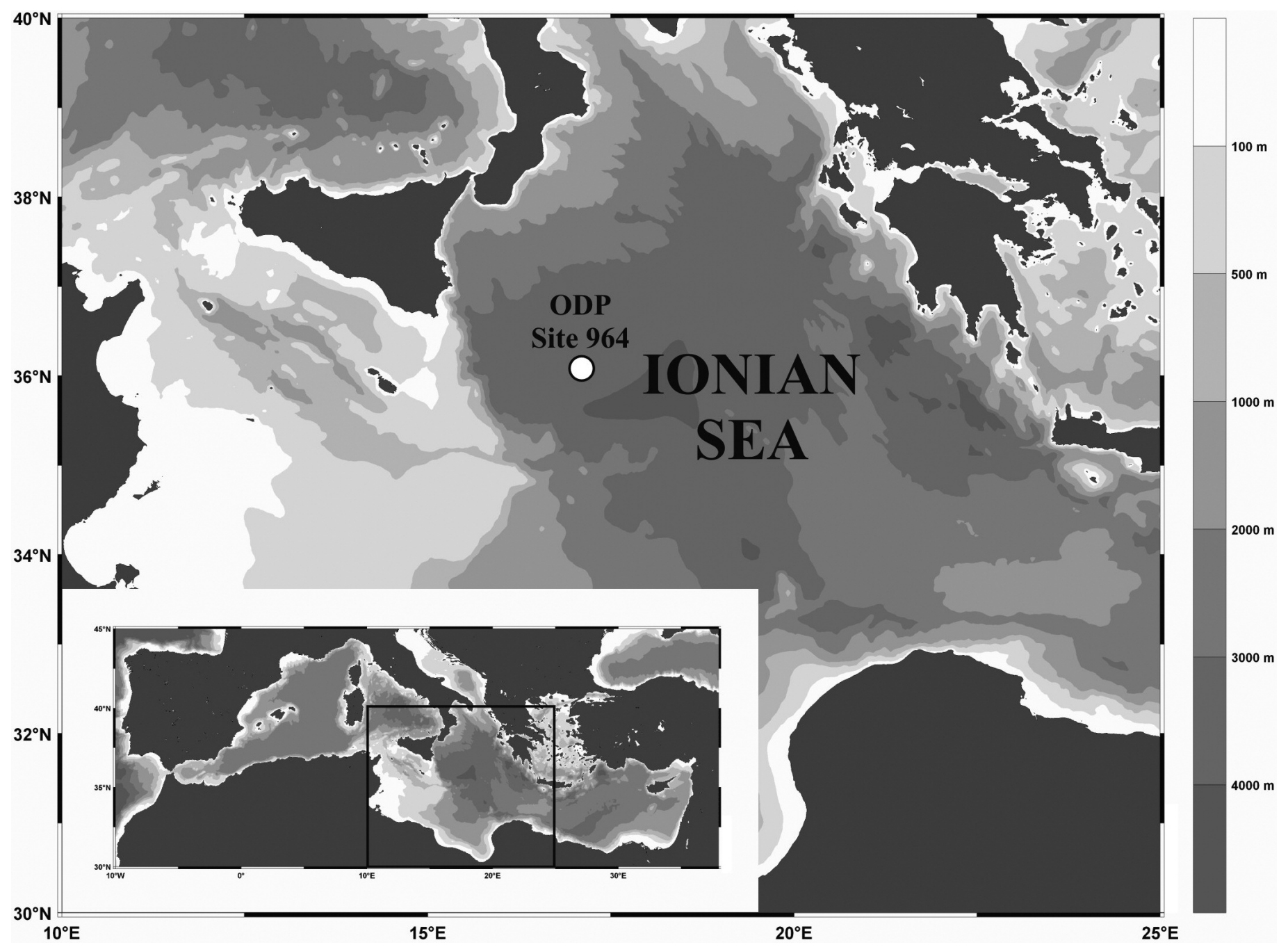

Fig. 2 - Bathymetric map of the Ionian Sea and location of the ODP Site 964. Inset below, the map of the Mediterranean basin.

G. oceanica and G. omega. Gephyrocapsa muellerae shows a few positive peaks, up to about $16 \%$, in the lower part of the record. G. oceanica and G. caribbeanica increase in abundance, with values up to respectively $10 \%$ and $25 \%$ respectively, mainly during Zones MNN 19c and MNN $19 \mathrm{~d}$. After the re-entrance of medium sized gephyrocapsids, G. oceanica is rather sparse. Gephyrocapsa omega, however, is the only species that successfully competes with very small Gephyrocapsa (fig. 3).

Coccolith size measurements on specimens $>3 \mu \mathrm{m}$ of the genus Gephyrocapsa show a rather gradual increasing trend from the base of the studied interval. After an interval with only specimens of Gephyrocapsa $<4 \mu \mathrm{m}$ (MNN $19 \mathrm{e})$, there is a new radiation of medium sized Gephyrocapsa (fig. 4).

The First Occurrence (FO) of Gephyrocapsa $\geq 4 \mu \mathrm{m}$ at $58.62 \mathrm{rmcd}$ is composed of specimens of $G$. caribbeanica and is not therefore able to mark the base of MNN 19b, which is defined by the FO of Gephyrocapsa oceanica sensu lato $>4 \mu \mathrm{m}$ (Rio et alii, 1990). The first occurrence of specimens of Gephyrocapsa $>5.5 \mu \mathrm{m}$ was observed at $49.1 \mathrm{rmcd}$ and a few specimens of Gephyrocapsa $\geq 4 \mu \mathrm{m}$ immediately above this horizon were considered as reworked. Finally, the re-entrance of medium-sized specimens occurred at 33.94 rmcd (fig. 3).
Florisphaera profunda shows wide abundance fluctuations between about $3 \%$ and $60 \%$. Positive peaks are usually associated to odd (interglacial) Marine Isotopic Stages (MIS) or to sapropel layers, for instance at 56.92, 56.42 and 55.82 rmcd. The lowest percentage values are recorded in coincidence of even (glacial) MIS (fig. 4). However the comparison is not always unambiguous and shows low abundance values for instance in coincidence of MIS 41, 45 and 65.

\section{DISCUSSION}

\section{BIOSTRATIGRAPHIC IMPLICATIONS}

Biostratigraphic boundaries MNN 19a/MNN 19b, MNN 19c/MNN 19d, MNN 19d/MNN 19e and MNN 19e/MNN 19f, marked by Gephyrocapsa spp. horizons, are constantly shifted above, with respect to SPROVIERI et alii (1998). These displacements, between 0.3 and 0.9 metres, can readily be explained by different methodologies, such as sampling strategy and the number of counted specimens, that may have affected the accuracy of the determinations of the biohorizons.

The First Common Occurrence (FCO) of Gephyrocapsa $>4.5 \mu \mathrm{m}$ and the FO of Gephyrocapsa $>5.0 \mu \mathrm{m}$ fall very close 


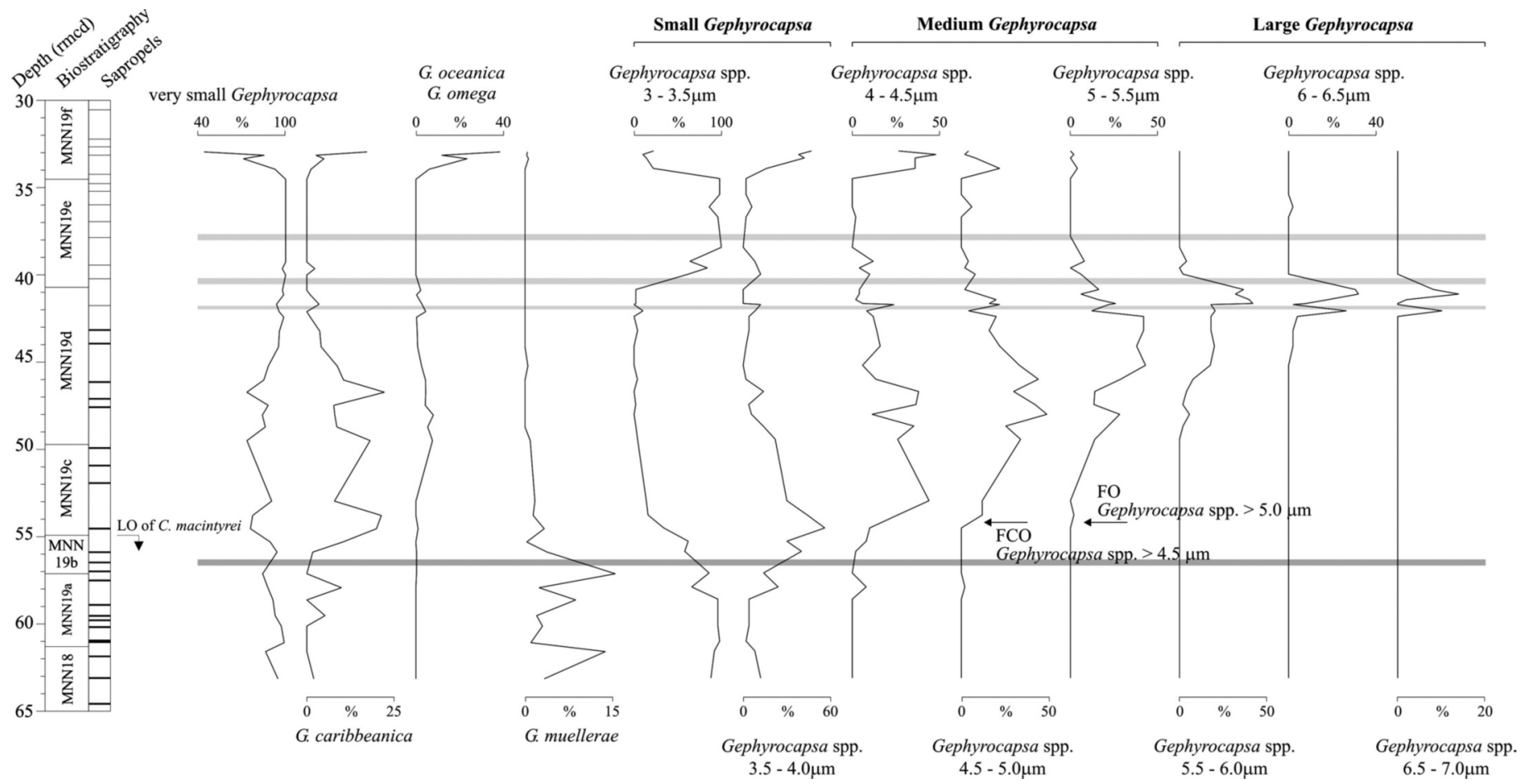

Fig. 3 - Downcore variations of biometric and compositional data of the genus Gephyrocapsa collected at the ODP Site 964 during the Early Pleistocene, plotted versus depth in rmcd. From the left, the biostratigraphic framework, following SPRoviERI et alii (1998); Sapropel layers setting (EMEIS et alii, 2000b); Relative abundance of the taxonomic units, very small Gephyrocapsa, G. caribbeanica, G. oceanica, G. omega and G. muellerae identified in the study; Biometric data collected on the long axis of placoliths, grouped every $0.5 \mu \mathrm{m}$. Taxonomic units used by Rio et alii (1990) for biostratigraphic purposes, small Gephyrocapsa, medium Gephyrocapsa and large Gephyrocapsa are also indicated. Black arrows mark biohorizons that may reinforce the LO of $C$. macintyrei in terrigenous sections. Light grey bands show sample where severe dissolution processes led to the disappearance of most of Gephyrocapsa spp. specimens.

to the LO of $C$. macintyrei that defines the base of the MNN 19c Zone (fig. 3). It is well-established that the LO of $C$. macintyrei is time-transgressive when low-latitude Atlantic and Pacific sites are compared with middle-latitude Atlantic sites, occurring $43 \mathrm{kyr}$ earlier in Atlantic middle-latitude sites (RAFFI et alii, 1993, 2006; RAFFI, 2002). A similar discrepancy is observed in the Mediterranean Sea, where this biohorizon seems to disappear from the sedimentary record within the MIS 59/58 transition in the eastern Mediterranean Sea (RAFFI, 2002; RAFFI et alii, 2006) and in the upper part of MIS 56 in the western Mediterranean Sea (DE KAENEL et alii, 1999). In the composite ODP Site 964 record from the Ionian Sea, the LO of $C$. macintyrei occurs within MIS 56 (SPROVIERI et alii, 1998), similar to its disappearance horizon in the western Mediterranean Sea. The gap between the FCO of Gephyrocapsa $>4.5 \mu \mathrm{m}$ and the FO of Gephyrocapsa $>5.0$, identified within MIS 55 (figs. 3-4), is less than the duration of a full glacial/interglacial cycle. The FCO of Gephyrocapsa $>4.5 \mu \mathrm{m}$ and the FO of Gephyrocapsa $>5.0 \mu \mathrm{m}$ may thus approximate the detectment of the LO of C. macintyrei in terrigenous sediments where reworking masks this signal. This problem is especially important in terrigenous land sections of southern Italy and Sicily, where most of Pliocene-Pleistocene Global Stratigraphic Sections and Points and historical reference sections outcrop (CITA et alii, 2006, 2008).

\section{ENVIRONMENTAL INFLUENCE ON GRADUAL SIZE INCREASE}

Measurements on the long axis of the genus Gephyrocapsa highlight a clear gradual size increase in minima, average and maxima values, from the upper part of MNN $19 \mathrm{a}$ to the top of MNN 19d Zones (fig. 4). The mean value of these $\geq 3.0 \mu \mathrm{m}$ placoliths increases from $3.0-3.5 \mu \mathrm{m}$ to about $6.0 \mu \mathrm{m}$

Several paleoclimatic/paleoenvironmental studies have been carried out on the sediments of the ODP Site 964 and of the Ionian Sea (NEGRI et alii, 1999; EMEIS et alii, 2000a; NEgRI \& GIUNTA, 2001; GerAgA et alii, 2008; INCARBONA et alii, 2011; MAIORANO et alii, 2013). We show $\delta^{18} \mathrm{O}$ data collected on shells of the planktonic foraminifera species Globigerina bulloides (fig. 4) representing global ice volume fluctuations and local sea surface temperature (SST) and salinity variations (SPROVIERI et alii, 1998). We also show abundance fluctuations of $F$. profunda (fig. 4), a proxy for primary productivity levels (CASTRADORI, 1993; INCARBONA et alii, 2008, 2011). The oxygen isotope and $F$. profunda records demonstrate that environmental conditions, such as SST/salinity and nutrient dynamics, oscillated with glacial/interglacial changes. Given the relatively steady size increase in Gephyrocapsa spp. specimens, we suggest that variable conditions in the photic zone environments induced by glacial/interglacial oscillations did not have any obvious effect on the size evolution of gephyrocapsids. However, we note that the time interval between 2.0 and $1.2 \mathrm{Ma}$ is characterized by a linear trend towards heavier oxygen isotopic values, due to the growth of ice sheets (LISIECKI \& RAYMo, 2005). Also suspect is the timing of the disappearance of specimens of Gephyrocapsa spp. $>4.0 \mu \mathrm{m}$ at the base of biozone MNN 19e. It coincides with the Middle Pleistocene Transition (MPT), the most recent re- 


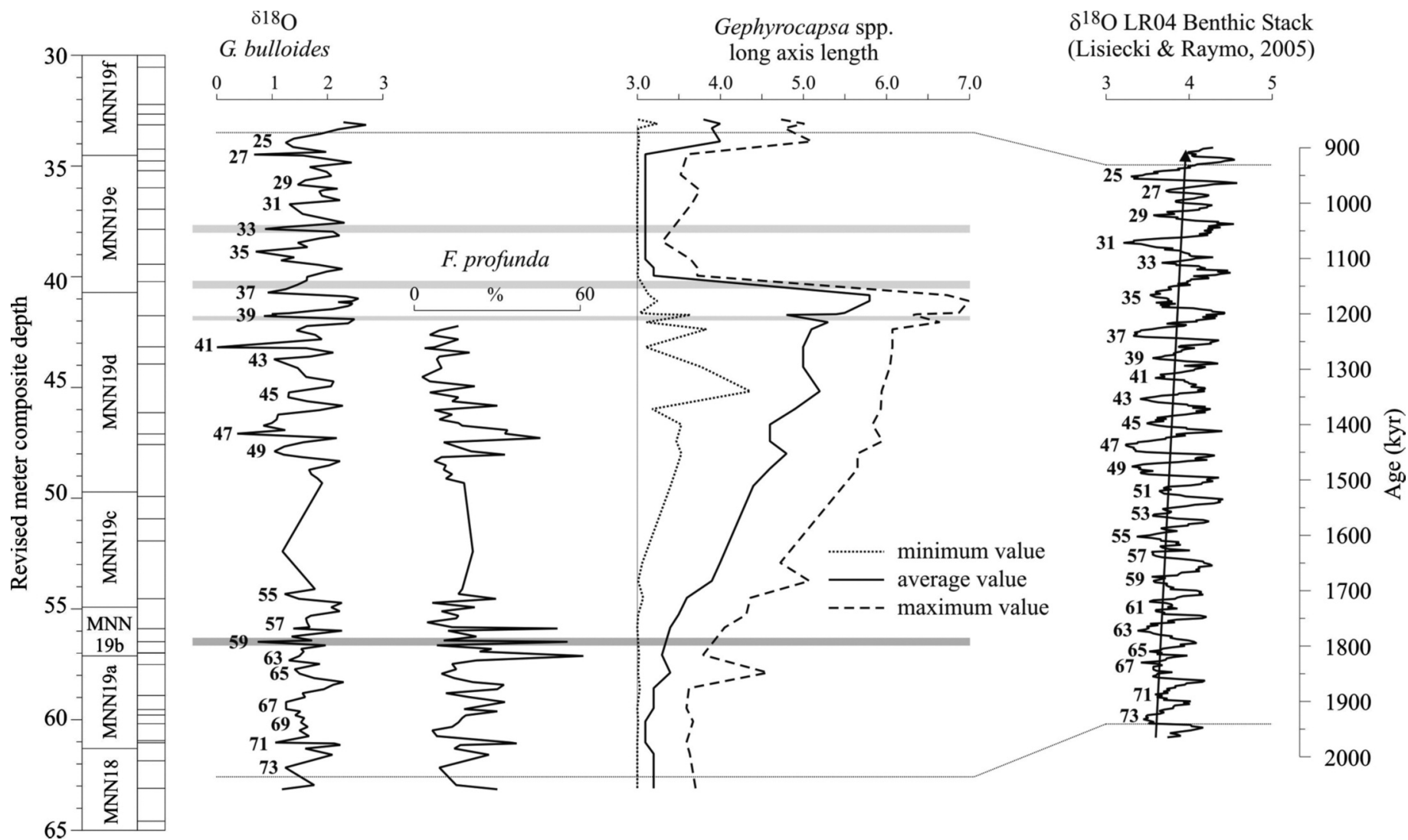

Fig. 4 - Comparison of biometric data of the genus Gephyrocapsa and environmental proxy data at the ODP Site 964 during the Early Pleistocene, plotted versus depth in rmcd. From the left, the biostratigraphic framework, following SPROviERI et alii (1998); Sapropel layers' setting (EMEIS et alii, 2000b); Oxygen isotope values collected on the shells of $G$. bulloides (SPROVIERI et alii, 1998); Downcore variations of $F$. profunda; Minima, medium and maxima values in the long axis of placoliths of Gephyrocapsa spp. specimens; Oxygen isotope values of the LR04 Benthic Stack (LisiEcKi \& RAYMO, 2005) and their linear trend (black arrow). Light grey bands show sample where severe dissolution processes led to the disappearance of most of Gephyrocapsa spp. specimens. Dotted lines indicate the correlation between MIS of ODP 964 and the LR04 Benthic Stack.

organization of the global climate system that involved, among others, changes in the amplitude of glacial/interglacial cycles, an increase in ice sheets volume, SST cooling in the oceans, variations in the Atlantic Meridional Overturning Circulation, a significant drop in $\mathrm{CO}_{2}$ atmospheric levels (RUDDIMANN et alii, 1989; HodELL et alii, 2003; LISIECKI \& RAYMO, 2005; CLARK et alii, 2006).

We suggest that the influence of the climate and of the environment on size variations of the genus Gephyrocapsa, if any, would have acted on time scales that were longer than glacial/interglacial cycles. For instance the linear trend in ice sheet growth, may have had a global impact on the marine realm and are therefore compatible with the report of the increasing size of Gephyrocapsa placoliths from all oceans.

\section{CONCLUSION}

Biometric and compositional data of Gephyrocapsa spp. were collected with a resolution of about $20 \mathrm{kyr}$ in early Pleistocene sediments of the ODP Site 964 (Ionian Sea, eastern Mediterranean).

We discuss the influence of the environmental/climatic forcing on the size increasing trend of placoliths of this genus and conclude that only long-scale phenomena, such as the trend observed in the growth of ice sheets and the subsequent SST cooling in oceans, may have had a role in Gephyrocapsa spp. size variations. Finally, we point out that the FCO of Gephyrocapsa $>4.5 \mu \mathrm{m}$ and the FO of Gephyrocapsa $>5.0 \mu \mathrm{m}$ occur close to the LO of C. macintyrei. As the LO of $C$. macintyrei, that defines the base of the Zone MNN 19c in Mediterranean biostratigraphic schemes (RIO et alii, 1990), is difficult to determine in terrigenous land sections having much reworking, these two biohorizons may be used in biostratigraphic studies.

\section{ACKNOWLEDGMENTS}

We are grateful to Jan Backman and Isabella Raffi for their helpful comments. This work was financially supported by MIUR ex $60 \%$ grants to E. Di Stefano.

\section{REFERENCES}

Antoine D., Morel A. \& André J.M. (1995) - Algal pigment and primary production in the eastern Mediterranean as derived from CZCS observations. Journal of Geophysical Research, 100, 16193-16210.

BollmanN J. (1997) - Morphology and biogeography of Gephyrocapsa coccoliths in Holocene sediments. Marine Micropaleontology, 29, 319-350.

Bosc E., BRICAud A. \& ANTOINe D. (2004) - Seasonal and interannual variability in algal biomass and primary production in the Medi- 
terranean Sea, as derived from 4 years of seaWiFS observations. Global Biogeochemical Cycles, 18. doi: 10.129/2003GB002034.

Bown P.R. \& Young J.R. (1998) - Techniques. In: Bown P.R. (ed.), Calcareous Nannofossil Biostratigraphy, Kluwer Academic Publishers, Dordrecht, Boston, London, 16-32.

BRÉHÉRET J.G. (1978) - Formes nouvelles quaternaries et actuelles de la famille des Gephyrocapsaceae (Coccolithophorides). C.R. Acad. Sci., Ser. D, 287, 447-449.

BUKRY D. (1973) - Low-latitude coccolith biostratigraphic zonation. In: Edgard N.T. \& Saunders J.B. et alii (eds.), Deep-Sea Drilling Project Initial Reports, 15, 685-703.

CASTRADORI D. (1993) - Calcareous nannofossils and the origin of eastern Mediterranean sapropels. Paleoceanography, 8, 459-471.

Cita M.B., Capraro L., Ciaranfi N., Di Stefano E., Lirer F., Maiorano P., Marino M., Raffi I., Rio D., Sprovieri R., SteFANELli S. \& VAi G.B. (2008) - The Calabrian Stage redefined. Episodes, 31, 418-429.

Cita M.B., Capraro L., Ciaranfi N., Di Stefano E., Marino M., Rio D., SPROVIERI R. \& VAI G.B. (2006) - Calabrian and Ionian: A proposal for the definition of Mediterranean stages for the Lower and Middle Pleistocene. Episodes, 29, 107-114.

Clark P.U., ARcher D., Pollard D., Blum J.D., Rial J.A., Brovkin V., Mix A.C., Pisias N.G. \& Roy M. (2006) - The middle Pleistocene transition: characteristics, mechanisms and implications for long-term changes in atmospheric $\mathrm{pCO}_{2}$. Quaternary Science Reviews, 25, 3150-3184.

De Kaenel E., Siesser W.G. \& Murat A. (1999) - Pleistocene calcareous nannofossil Biostratigraphy and the Western Mediterranean sapropels, Sites 974, 977 and 979. In: Zahn R., Comas M.C. \& Klaus A. (eds.), Proceedings of the Ocean Drilling Program, Scientific Results, 161, 159-183.

Di Stefano E. \& InCARBona A. (2008) - Calcareous nannofossil biostratigraphy and chronostratigraphy of ODP Hole 964D (Eastern Mediterranean Sea). Rivista Italiana di Paleontologia e Stratigrafia, 114, 313-322.

D'Ortenzio F., Ragni M., Marullo S. \& Ribera D'Alcalà M. (2003) - Did biological activity in the Ionian Sea change after the Eastern Mediterranean Transient? Results from the analysis of remote sensing observations. Journal of Geophysical Research C, Oceans, 108, 14-20.

D'ORTENZIO F. \& Ribera D'Alcalà M. (2009) - On the trophic regimes of the Mediterranean Sea: a satellite analysis. Biogeosciences, $\mathbf{6}$, 139-148.

Emeis K.-C., Robertson A.H.F. \& Richter C. et alii (1996) - Site 964. Proceedings of the Ocean Drilling Program, Initial Report, 160, 85-123.

Emeis K.C., SaKamoto T., Wehausen R. \& Brumsack H.J. (2000b) The sapropel record of the eastern Mediterranean Sea. Results of Ocean Drilling Program Leg 160. Palaeogeography, Palaeoclimatology, Palaeoecology, 158, 371-395.

Emeis K.-C., Struck U., Schulz H.-M., Rosenberg R., BernascoNi S., ERlenkauser H., SaKamoto T. \& Martinez-Ruiz F. (2000a) - Temperature and salinity variations of Mediterranean Sea surface waters over the last 16,000 years from records of planktonic stable oxygen isotopes and alkenone unsaturation ratios. Palaeogeography, Palaeoclimatology, Palaeoecology, 158, 259-280.

GARD G. (1988) - Late Quaternary calcareous nannofossil biozonation, chronology and paleoceanography in areas north of Faeroe-Iceland Ridge. Quaternary Science Reviews, 7, 65-78.

GARTNER S. (1977) - Calcareous nannofossil biostratigraphy and revised zonation of the Pleistocene. Marine Micropaleontology, 2, 1-25.

Geraga M., Mylona G., Tsaila-Monopoli S. \& Papatheodorou G. \& Ferentinos G. (2008) - Northeastern Ionian Sea: Palaeoceanographic variability over the last $22 \mathrm{ka}$. Journal of Marine Systems, 74, 623-638.

Hodell D.A., Venz K.A., Charles C.D. \& Ninneman U.S. (2003) Pleistocene vertical carbon isotope and carbonate gradients in the South Atlantic sector of the Southern Ocean. Geochemistry, Geophysics, Geosystems, 4. doi: 10.1029/2002GC000367.

Incarbona A., Di Stefano E. \& Bonomo S. (2009) - Calcareous Nannofossil Biostratigraphy of the Central Mediterranean Basin during the last 430000 years. Stratigraphy, 6, 33-44.
Incarbona A., Di Stefano E., Patti B., Pelosi N., Bonomo S., MaZzola S., Sprovieri R., Tranchida G., Zgozi S. \& BonanNo A. (2008) - Holocene millennial-scale productivity variations in the Sicily Channel (Mediterranean Sea). Paleoceanography, 23, 1-18.

Incarbona A., Ziveri P., Sabatino N., Salvagio Manta D. \& SPRoVIERI M. (2011) - Conflicting coccolithophore and geochemical evidence for productivity levels in the Eastern Mediterranean sapropel S1. Marine Micropaleontology, 81, 131-143.

Kamptner E. (1943) - Zur Revision der Coccolithen-Species Pontosphaera huxleyi Lohmann. Anzeiger der Akademie der Wissenschaen, 80, 43-49.

Krom M.D., Emeis K.-C. \& VAN Cappellen P. (2010) - Why is the Eastern Mediterranean phosphorus limited? Progress in Oceanography, 85, 236-244.

LisIECKI L.E. \& RAYMO M.E. (2005) - Pliocene-Pleistocene stack of 57 globally distributed benthic $\delta^{18} \mathrm{O}$ records. Paleoceanography, 20. doi: 10.1029/2004PA001071.

Lourens L.J. (2004) - Revised tuning of Ocean Drilling Program Site 964 and $\mathrm{KCO1B}$ (Mediterranean) and implications for the $\delta^{18} \mathrm{O}$, tephra, calcareous nannofossil, and geomagnetic reversal chronologies of the past 1.1 Myr. Paleoceanography, 19. doi: 10.1029/ 2003 PA000997.

Maiorano P., Tarantino F., Marino M. \& De Lange G.J. (2013) Paleoenvironmental conditions at Core KCO1B (Ionian Sea) through Oxygen Isotope Stages 9-13: evidences from calcareous nannofossil assemblage. Quaternary International, 288, 97-111.

MARTINi E. (1971) - Standard Tertiary and Quaternary calcareous nannoplankton zonation. In: Farinacci A. (ed.), Proceedings II Planktonic. Tecnoscienze, Rome, 2, 739-785.

MATSUOKA H. \& OKADA H. (1990) - Time-progressive morphometric changes of the genus Gephyrocapsa in the Quaternary sequence of the tropical Indian Ocean, Site 709. In: Duncan R.A., Backman J. \& Peterson L.C. (eds.), Proceedings of the Ocean Drilling Program, Scientific Results, 115, Ocean Drilling Program, College Station, TX, 255-270.

NegRi A. \& GiUnTA S. (2001) - Calcareous nannofossil paleoecology in the sapropel S1 of the eastern Ionian sea: paleoceanographic implications. Palaeogeography Palaeoclimatology Palaeoecology, 169, 101-112.

Negri A., CAPotondi L. \& Keller J. (1999) - Calcareous nannofossils, planktonic foraminifera and oxygen isotopes in the late Quaternary sapropels of the Ionian Sea. Marine Geology, 157, 89-103.

OvchinNIKOV I.M. (1984) - The formation of Intermediate Water in the Mediterranean. Oceanology, 24, 168-173.

PinARDI N. \& MASETTI E. (2000) - Variability of the large scale general circulation of the Mediterranean Sea from observations and modelling: a review. Palaeogeography, Palaeoclimatology, Palaeoecology, 158, 153-174.

PIRINI-RAdDRIZZANi C. \& VAlleri G. (1977) - New data on calcareous nannofossils from the Pliocene of the Tyrrhenian Basin Site 132 DSDP, Leg 13. Rivista Italiana di Paleontologia e Stratigrafia, 83, 897-924.

Poem Group (1992) - General circulation of the Eastern Mediterranean. Earth-Science Reviews, 32, 285-309.

Pujos-Lamy A. (1976) - Emiliania et Gephyrocapsa (Nannoplancton calcaire); Biometrie et interet biostratigraphique dans le Pleistocene superieur marine des Acores. Rev. Espan. Micropal., 9, 69-84.

RAFFI I. (2002) - Revision of the early-middle Pleistocene calcareous nannofossil biochronology (1.75-0.85 Ma). Marine Micropaleontology, 45, 25-55.

RAFFI I. \& Rio D. (1979) - Calcareous nannofossils biostratigraphy of DSDP Site 132, Leg 13 (Tyrrhenian Sea-Western Mediterranean). Rivista Italiana di Paleontologia e Stratigrafia, 85, 127-172.

RafFi I., Backman J., Fornaciari E., Palike H., Rio D., Lourens L. \& HiLGEN F. (2006) - A review of calcareous nannofossil astrobiochronology encompassing the past 25 millions years. Quaternary Science Reviews, 25, 3113-3137.

Raffi I., Backman J., Rio D. \& Shackleton N.J. (1993) - Plio-Pleistocene nannofossil biostratigraphy and calibration to oxygen isotopes stratigraphies from Deep-Sea Drilling Project Site 607 and Ocean Drilling Program Site 677. Paleoceanography, 8, 387-408.

Rio D. (1982) - The fossil distribution of coccolithophore genus Gephyrocapsa Kamtner and related Plio-Pleistocene chronostrati- 
graphic problems. In: Prell W.L. et alii (eds.), Deep-Sea Drilling Project Initial Reports, 68, 325-343.

Rio D., RAFfi I. \& Villa G. (1990) - Pliocene-Pleistocene calcareous nannofossil distribution patterns in the western Mediterranean. In: Kastens K.A. (ed.), Proceedings of the Ocean Drilling Program, Scientific Results, 107, 513-533.

Ruddimann W., Raymo M., Martinson D., Clement B. \& BaCKMAN J. (1989) - Pleistocene evolution: Northern Hemisphere ice sheets and North Atlantic Ocean. Paleoceanography, 4, 353-412.

SAKamoto T., JaneceK T. \& EMEIS K.-C. (1998) - Continuous sedimentary sequences from the eastern Mediterranean sea: composite depth sections. In: Emeis K.-C., Robertson A.H.F., Richter C. \& Camerlenghi A. (eds.), Proceedings of the Ocean Drilling Program, Scientific Results, 160, 37-59.
Samtleben C. (1980) - Die Evolutio der Coccolithophoriden-Gattung Gephyrocapsa nach Befunden im Atlantik. Palaont. Z., 54, 91-127.

Sprovieri R., Di Stefano E., Howell M., Sakamoto T., Di StefaNO A. \& MARINO M. (1998) - Integrated calcareous plankton biostratigraphy and cyclostratigraphy at Site 964. In: Emeis K.-C., Robertson A.H.F., Richter C. \& Camerlenghi A. (eds.), Proceedings of the Ocean Drilling Program, Scientific Results, 160, 155-165.

Sprovieri R., Di Stefano E., Incarbona A. \& Gargano M.E. (2003) - A high-resolution record of the last deglaciation in the Sicily Channel based on foraminifera and calcareous nannofossil quantitative distribution. Palaeogeography Palaeoclimatology Palaeoecology, 202, 119-142. 